ECONOMICS

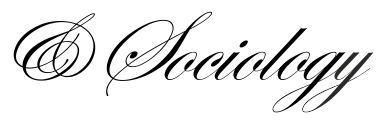

\author{
Tetyana Blyznyuk, \\ Simon Kurnets Kharkiv National \\ University of Economics, \\ Kharkiv, Ukraine, \\ E-mail: \\ tetyana.blyznyuk@bneu.net
}

Received: February, 2017

1st Revision: March, 2017

Accepted: July, 2017

DOI: $10.14254 / 2071-$

789X.2017/10-3/11
Blyznyuk, T. (2017). Generational Values of Generation Y: Survey of Ukrainian Senoir School Pupils and Students. Economics and Sociology, 10(3), 153-166. doi:10.14254/2071-789X.2017/10-3/11

\section{GENERATIONAL VALUES OF GENERATION Y: SURVEY OF UKRAINIAN SENOIR SCHOOL PUPILS AND STUDENTS}

\begin{abstract}
The aim of this study is to evaluate the generational values of Ukrainian generation $\mathrm{Y}$ on the basis of evaluation, comparison and analysis of the generational values' structure of the senior school pupils and students, using M. Rokeach's approach. In the questionnaire which was conducted during October-December 2016 in Kharkiv (Ukraine), two groups of respondents took part: senior pupils of the Kharkiv gymnasium \#47 and students of the Simon Kuznets Kharkiv National University of Economics. As a result of the research, it was established that the dominant values in life of Ukrainian generation $\mathrm{Y}$ are family values (family creation, procreation, and care for parents). This generation is also focused on achieving significant success in business, self-development, career growth and goals achievement. The results of the study on the structure of values of generation $\mathrm{Y}$ will make it possible to develop recommendations concerning the adaptation of personnel management systems in accordance with the values' profile of this generation that is now becoming part of adult population in Ukraine.
\end{abstract}

JEL Classification: Z1, Z13

Keywords: generation $\mathrm{Y}$, generational values of generation $\mathrm{Y}$, generational theory, M. Rokeach's approach, conflict of generations

\title{
Introduction
}

One of the most recent theories of cyclical development of the society is the theory of generations, which was developed by N. Howe and W. Strauss. According to this theory (Howe, Strauss, 2007), each generation has its own generational values, which differ from the values of other generations, formed in previous or subsequent periods of time. At the same time, when the next generation is being brought up, not those values that are important for the current generation are generated and transferred, but primarily those values that were lacking in the life of parents' generation.

Each generation has been going through the process of socialization at different time, that's why the systems of values of the generations don't match and may even experience certain clashes (Lepeyko, Blyznyuk, 2016a). Therefore, the root cause of any conflict between generations is the divergence in the values of the generations of children and parents.

In order to effectively eliminate the problems arising in personnel management when there are representatives of different generations, that is, to reduce the negative impact from the conflict of generations, it is necessary to know the key features of each generation, 
namely, the system of their basic values. Once these basic values are being taken into account, the system of personnel management will significantly improve its own internal efficiency as well as efficiency of the entire organization.

\section{Literature review}

The present generational theory was created in 90 s of XX century by N. Hall and W. Strauss. The basis of the theory of generations (Hall, Strauss, 2007), is the fact that the value systems of people who have grown up in different historical periods, that is, belong to different generations, differ much. This is due to the fact that human values are formed not only as a result of family upbringing, but also under the influence of social events that occur during a person's growing up, such as economic, social, technological and political events. That is why the defining characteristic of each generation is a list of basic values of this generation, which distinguishes this generation from the previous one.

Various practical researches of different aspects of personnel management's motivation, education and promotion were conducted on the basis of the theory. Thus, in her work A. Ermolenko (Ermolenko, 2015) examines the features of teaching different generations, taking into account their basic values. The researcher pays attention to the fact that mostly teachers are representatives of the generation $\mathrm{X}$ and baby boomers, while the students are representatives of generation Y. M. Isaeva (Isaeva, 2011) examines the main archetypes of generations in their relationship with the emergence of major youth subcultures and emphasizes the decisive role of the Internet in the life of representatives of the generation Y. I. Kostenko (Kostenko, 2013) in the study considers the features of personnel management, that is represented by the generation $\mathrm{X}$ and $\mathrm{Y}$, as the most numerous in the labor market of Ukraine. In his work V. Syumar (Syumar, 2013) analyzes in detail the features of modern generations of politicians in Ukraine. In Ukrainian politics, baby boomers are the most widely represented people. Representatives of the generation X actively compete with them. For active political actions representatives of generation $\mathrm{Y}$ are still too young. T. Lepeyko and T. Blyznyuk (Lepeyko, Blyznyuk, 2016a) in their study based on a comparative analysis of the main values of representatives of modern generations of modern Western Europe and Ukraine, have revealed almost complete absence of the influence of the territorial factor on generation formation. M. Ueberwimmer and T. Blyznyuk (Blyznyuk, Ueberwimmer, 2016) revealed the features of cross-cultural profiles of modern managers of different generations in Western Europe and Ukraine. T. Lepeyko and T. Blyznyuk (Lepeyko, Blyznyuk, 2016b) in their study created a profile of the modern Ukrainian manager, a representative of the generation $\mathrm{X}$, as the leader in Ukrainian management.

Every year, the number of representatives of generation $\mathrm{Y}$ in the structure of the personnel of modern companies increases, gradually replacing the representatives of the baby boomer generation. According to a study by scientists (Blyznyuk, Ueberwimmer, 2016), the formation of the basic values of generation $\mathrm{Y}$ in Ukraine is completed in the middle of the 2010s.

The aim of the research is to determine the basic values of the representatives of Ukrainian generation Y on the basis of Rokeach's approach and to achieve this aim there are the following tasks:

to get a survey of the representatives of generation $\mathrm{Y}$ in order to determine basic (generational) values;

to determine and analyze the structure of basic (generational) values of Ukrainian generation Y (terminal and instrumental);

to make up a profile of generational values of Ukrainian generation Y. 


\section{Methodological approach}

Rokeach's value survey (RVS) is one of the most popular approaches to assessing the basic values of groups of individuals. This approach (Rokeach, 1979) is aimed at investigating individual (or group) ideas about a system of significant values that determine the basic life guides of an individual (group).

D. Debats and B. Bartelds (Debats, Bartelds, 1996) note in their study that the popularity of the Rokeach's approach is based on the fact that the definition of the system and the value structure of an individual or a group of people allows one to determine their basic (dominant) values and to diagnose the presence or absence of contradictions between values.

Thus, the researchers M. Gorbatova and M. Ljahova (Gorbatova, Ljahova, 2005), L. Safiullina and N. Zotkin (Safiullina, Zotkin, 2007), N. Skrynko and K. Lozna (Skrynko, Lozna, 2013), G. Galkina and E. Gribkova (Galkina, Gribkova, 2013) on the basis of M. Rokeach's approach assessed the value system of university students. Also, based on M. Rokeach's approach, the scientists E. Dunaevskaja (2008) and Yu. Soshyna (Soshyna, 2013) investigated the peculiarities of the value system of schoolchildren.

As D. Leontiev (Leontiev, 1992) notes in his research, most modern approaches to the study of the value system of personality are based on M. Rokeach's approach.

M. Rokeach's approach is based on the direct ranking of value lists (Rokeach, 1979):

1) terminal (value-aims) - belief that an end goal of individual existence (e.g. happy family life, peace in the world) is worth craving from personal and societal point of view.

2) instrumental (value-ways) - belief that a way of action (e.g. honesty, rationality) is the best in any situation from personal and societal point of view.

These two lists of interrelated values were obtained by M. Rokeach (Rokeach, 1973) by excluding synonymous forms from bigger lists of values. Value-aims are achieved due to value-ways in the priorities that were determined by the respondent at the certain stage of the reflection of the life situation and himself.

In our study, the variant of M. Rokeach's approach which was adapted by D. Leontiev (Leontiev, 1992), in which two lists of terminal and instrumental values are presented in alphabetical order, was used. According to this approach, terminal values, and then instrumental values, are evaluated.

In the survey two categories of respondents took part: pupils of 9-11 forms of Kharkiv gymnasium № 47 and the 1-5 year students of Management and Marketing Faculty of Simon Kuznets Kharkiv National University of Economics. The survey was conducted in the period of October-December in 2016 in Kharkiv (Ukraine).

\section{Conducting research and results}

Generational values of each generation are formed till the age of 12-14 under the influence of both societal events (political, cultural, economic and social events that define the characteristics of technological progress) and the family upbringing (Kirvas, 2014), that is the reason the pupils (2000-2004 years of birth) and the students (1999-1994 years of birth) were chosen for the survey.

The total amount of the interviewed respondents consisted of two parts:1) 100 senior pupils (aged $14.5 \pm 1.5$ years), of whom $51.0 \%$ are males and $49.0 \%$ are females; 2) 100 students (aged $23.0 \pm 6.0$ years), of which $28.0 \%$ are males and $72.0 \%$ are females.

The age and gender structure of the two groups of respondents is shown in the Table 1.

During the first 14 years of life, all respondents were on the territory of Ukraine, that is, the process of their socialization and the formation of the structure of terminal values passed among all respondents under the same conditions of the Ukrainian national culture. 
Table 1. Age and gender structure of respondents

\begin{tabular}{ccc}
\hline \multirow{2}{*}{ Age } & \multicolumn{2}{c}{ Gender, \% } \\
\cline { 2 - 3 } & male & female \\
\hline 13 & 14.00 & 11.00 \\
\hline 14 & 10.00 & 15.00 \\
\hline 15 & 13.00 & 12.00 \\
\hline 16 & 14.00 & 11.00 \\
\hline 17 & - & 6.00 \\
\hline 18 & 6.00 & 12.00 \\
\hline 19 & 3.00 & 11.00 \\
\hline 20 & 6.00 & 8.00 \\
\hline 21 & 6.00 & 8.00 \\
\hline 22 & 3.00 & 7.00 \\
\hline 23 & - & 1.00 \\
\hline 24 & - & 1.00 \\
\hline 25 & 1.00 & - \\
\hline 26 & 1.00 & 1.00 \\
\hline 27 & - & 2.00 \\
\hline 28 & 2.00 & 3.00 \\
\hline 29 & - & 2.00 \\
\hline
\end{tabular}

Source: own compilation.

\subsection{Terminal values analysis}

Respondents were offered the list of terminal values (Leontiev, 1992) and for each of them the respondents had to determine their priority and to choose the ranking number from 1 to 18 ( 1 - most important value, 18 - least important value) (Table 2).

Table 2. List of terminal values (D. Leontiev's approach)

\begin{tabular}{|c|c|c|}
\hline № & Terminal value & Value description \\
\hline 1 & 2 & 3 \\
\hline 1 & Active and interesting life & Abundant and emotional life \\
\hline 2 & Inner harmony & Self-confidence, freedom from inner conflicts, doubts \\
\hline 3 & Wisdom & $\begin{array}{l}\text { Mature judgments and common sense, which can be obtained } \\
\text { with the life experience }\end{array}$ \\
\hline 4 & Health & Physical and psychological health \\
\hline 5 & Interesting job & \\
\hline 6 & Love & Spiritual affinity and sex with the beloved person \\
\hline 7 & $\begin{array}{l}\text { Financially secured and } \\
\text { comfortable life }\end{array}$ & Absence of financial hardships \\
\hline 8 & Real friendship & Good and loyal friends \\
\hline 9 & Public recognition & Respect from the public, colleagues \\
\hline 10 & Knowledge & $\begin{array}{l}\text { Ability to further education, personal enrichment, general } \\
\text { culture, intellectual development }\end{array}$ \\
\hline 11 & Productive life & The usage of the abilities and capabilities to the fullest \\
\hline 12 & Development & $\begin{array}{l}\text { Self-development, life-long physical and spiritual } \\
\text { improvement }\end{array}$ \\
\hline 13 & Freedom & Independence in views and actions \\
\hline 14 & Aspirations beauty & Feeling the beauty in nature and art $\mathrm{i}$ \\
\hline
\end{tabular}




\begin{tabular}{rll}
\hline 1 & \multicolumn{1}{c}{2} & \\
\hline 15 & Happy family life & \\
\hline 16 & Happiness of others & $\begin{array}{l}\text { Well-being, development of other people, the whole nation } \\
\text { and humanity }\end{array}$ \\
\hline 17 & Art & Ability for art \\
\hline 18 & Pleasure & Entertainment, leisure time, absence of responsibilities \\
\hline
\end{tabular}

Source: Leontiev, 1992.

To get the group results for each of the values there has been a calculation of arithmetic mean of the place of each value according to the data of the whole group. And then the average results of the place of all the values are ranked for the second time in the order of increasing. The value with the lowest average place got rank 1; the next one got rank 2 and so on. The result of this procedure is the group hierarchy of value orientations.

To see the connection between the assessments of terminal values for each of the groups of respondents, the Pearson coefficients were calculated. For a group of students, Pearson's coefficients were in the range of $0,697 \div 0,929$, and for a group of senior pupils they were within the limits of $0,724 \div 0,936$. This indicates a high degree of consistency of points of view in each group of respondents when assessing terminal values. There was no significant influence of the gender factor.

The consistency of the ranking results of all terminal values by students and senior pupils was verified using the Spearman coefficient. Its empirical value was $\rho=0.077467$, with critical values $\rho=0.47(\mathrm{p} \leq 0.05)$ and $\rho=0.60(\mathrm{p} \leq 0.01)$. This indicates a high degree of consistency in the results of the ranking of terminal values among students and senior pupils. That is why, based on the results of the analysis of terminal values of students and senior pupils, it is possible to determine the basic terminal values of generation Y, which define their life position. Thus, the hierarchy of terminal values of representatives of Ukrainian generation Y was formed. It is presented on the Graph 1.

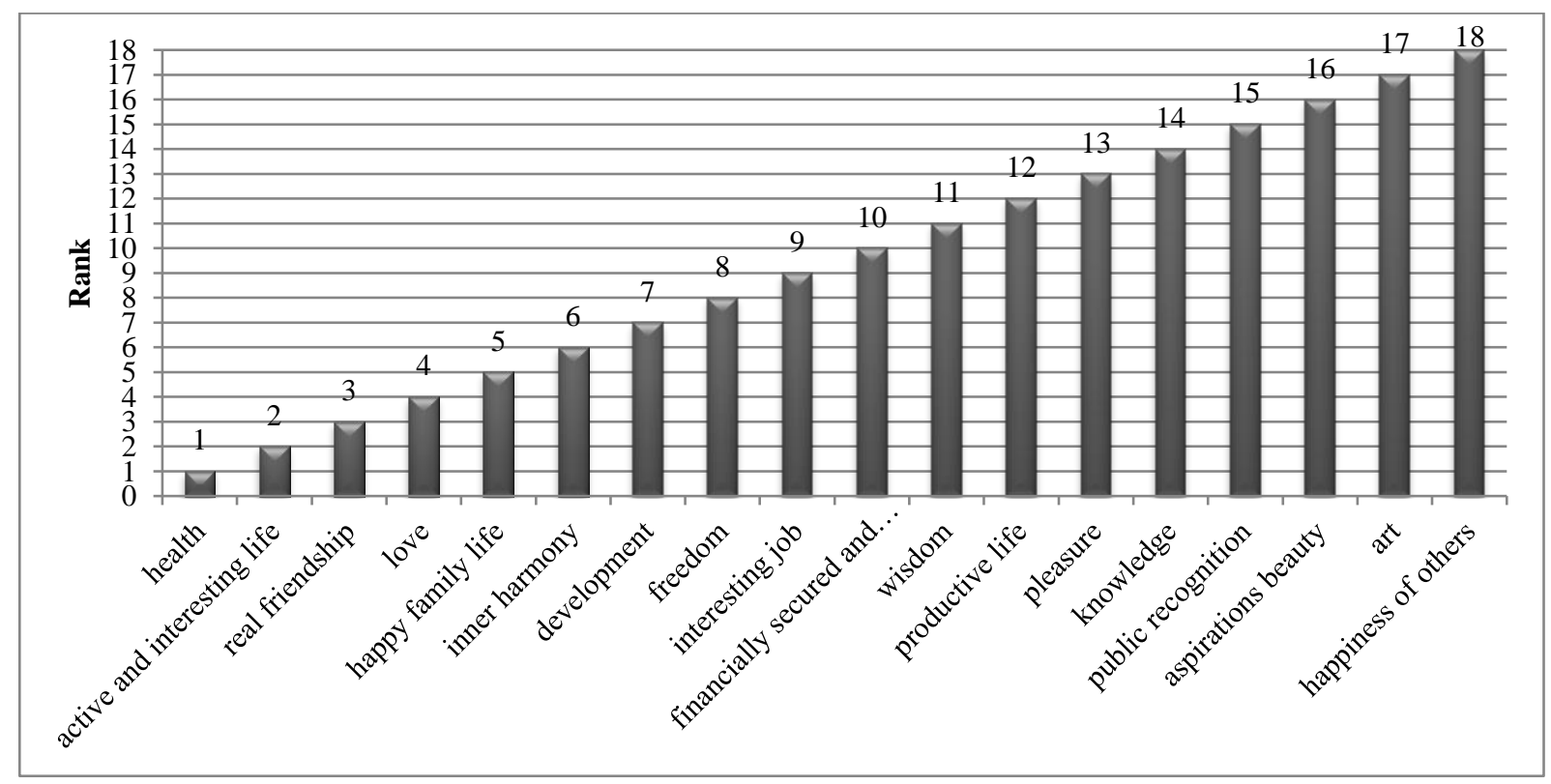

Graph 1. Hierarchy of terminal values of Ukrainian generation Y

Source: own data. 
Leading ranks (1-6 ranks) in the overall structure of the terminal values of Ukrainian generation Y are: "health", "active and interesting life", "real friendship", "love", "happy family life" and "inner harmony". Among the terminal values that are unimportant or absolutely rejected by generation Y (rank 16-18), senior pupils and students singled out such values as "the happiness of others", "art" and "aspirations beauty".

Further detailed analysis of the terminal values structure has been conducted in two basic directions (on the basis of D. Leontiev's approach (Leontiev, 1992)):

1) ratio of specific and abstract values;

2) ratio of private life and professional self-realization values.

A number of terminal values (e.g. health, inner harmony) can be related to the groups of specific or abstract values correspondingly. The results of the analysis of the ratio of specific and abstract values of the representatives of Ukrainian generation $\mathrm{Y}$ are shown in the Table 3.

Table 3. Ratio of specific and abstract values of Ukrainian generation Y

\begin{tabular}{lcccc}
\hline \multirow{2}{*}{ Value } & \multicolumn{2}{c}{ Senior school pupils } & \multicolumn{2}{c}{ Students } \\
\cline { 2 - 5 } & place* & rank & place* & rank \\
\hline Health & Specific & & & \\
\hline Real friendship & 5.95 & 1 & 4.01 & 1 \\
\hline Active and interesting life & 6.49 & 2 & 7.47 & 6 \\
\hline Interesting job & 6.52 & 3 & 7.08 & 4 \\
\hline Happy family life & 8.82 & 7 & 8.93 & 9 \\
\hline Financially secured and comfortable life & 9.06 & 9 & 6.88 & 3 \\
\hline Pleasure & 9.19 & 10 & 7.60 & 8 \\
\hline Productive life & 9.58 & 12 & 11.55 & 14 \\
\hline Public recognition & 10.75 & 14 & 9.31 & 11 \\
\hline & 11.88 & 15 & 12.87 & 15 \\
\hline Freedom & Abstract & & & \\
\hline Love & 8.35 & 4 & 9.27 & 10 \\
\hline Inner harmony & 8.56 & 5 & 5.85 & 2 \\
\hline Development & 8.82 & 6 & 7.48 & 7 \\
\hline Wisdom & 8.89 & 8 & 7.47 & 5 \\
\hline Knowledge & 9.40 & 11 & 10.76 & 12 \\
\hline Aspirations beauty & 9.88 & 13 & 11.08 & 13 \\
\hline Art & 12.12 & 16 & 14.02 & 16 \\
\hline Happiness of others & 13.04 & 17 & 14.71 & 18 \\
\hline
\end{tabular}

* arithmetic mean

Source: own data.

According to the results from the Table 3 the conclusion can be made that the most significant for the representatives of Ukrainian generation $\mathrm{Y}$ is the group of specific values as it is this group of values that got the highest ranks $(1-4,6-8$ ranks) from the respondents in comparison with the group of abstract values (2, 4-8 ranks correspondingly).

A number of terminal values such as interesting job or real friendship can be classified as the values of professional self-realization and values of private life correspondingly. The results of the analysis of the ratio of private life and professional self-realization values of the representatives of Ukrainian generation $\mathrm{Y}$ are shown in the Table 4. 
Table 4. Ratio of private life and professional self-realization values of Ukrainian generation $\mathrm{Y}$

\begin{tabular}{lcccc}
\hline \multicolumn{1}{c}{ Value } & \multicolumn{2}{c}{ Senior school pupils } & \multicolumn{2}{c}{ Students } \\
\cline { 2 - 5 } & place* & rank & place* & rank \\
\hline & Professional self-realization & & & \\
\hline Active and interesting life & 6.52 & 3 & 7.08 & 4 \\
\hline Interesting job & 8.82 & 7 & 8.93 & 9 \\
\hline Development & 8.89 & 8 & 7.47 & 5 \\
\hline Productive life & 10.75 & 14 & 9.31 & 11 \\
\hline Public recognition & 11.88 & 15 & 12.87 & 15 \\
\hline & Private life & & & \\
\hline Real friendship & 6.49 & 2 & 6.49 & 6 \\
\hline Freedom & 8.35 & 4 & 8.35 & 10 \\
\hline Love & 8.56 & 5 & 8.56 & 2 \\
\hline Happy family life & 9.06 & 9 & 9.06 & 3 \\
\hline Pleasure & 9.58 & 12 & 9.58 & 14 \\
\hline * arithe & & & &
\end{tabular}

* arithmetic mean

Source: own data.

According to the results from the Table 4 the conclusion can be made that the most significant for Ukrainian generation $\mathrm{Y}$ is the group of private life values. As private life values got the highest ranks (2-6 ranks) from the respondents in comparison with the group of professional self-realization values (3-5, 7, 8- ranks correspondingly).

Profiles of terminal values of senior school pupils and students are almost identical and it proves that both groups of the respondents belong to one generation Y.

Generally, the analysis results of terminal values prove that generation $\mathrm{Y}$ is more oriented to family values (approximately 54\% of significance in life) and to the interests of the close people which have the specific form of appearance (approximately 52\% of significance). Yet professional self-realization and abstract values have an important place in life of the generation $-46 \%$ and $48 \%$ correspondingly.

\subsection{Instrumental values analysis}

The respondents were offered the following list of instrumental values (Leontiev, 1992) and for each of them the respondents had to determine the significance in their lives and to choose the rank number from 1 to 18 ( 1 - most important value, 18 - least important value) (Table 5).

Table 5. List of instrumental values (D. Leontiev's approach)

\begin{tabular}{cll}
\hline$№$ & \multicolumn{1}{c}{ Instrumental value } & \multicolumn{1}{c}{ Value description } \\
\hline 1 & \multicolumn{1}{c}{2} & \multicolumn{1}{c}{3} \\
\hline 1 & Accuracy (cleanliness) & Ability to keep order in things and affairs \\
\hline 2 & High demands & High demands to life \\
\hline 3 & Manners and politeness & Good manners \\
\hline 4 & Buoyancy & Sense of humor and luck \\
\hline 5 & Intelligence and education & Wide knowledge \\
\hline 6 & Diligence & Discipline \\
\hline 7 & Independence & Ability to act independently \\
\hline 8 & Irreconcilability to shortcomings in themselves and others \\
\hline 9 & Responsibility & Sense of obligation, ability to keep promise \\
\hline 10 & Rationalism & Ability to think logically and to take rational decisions \\
\hline
\end{tabular}




\begin{tabular}{rll}
\hline 1 & \multicolumn{1}{c}{2} & \multicolumn{1}{c}{3} \\
\hline 11 & Self-control & Restraint, self-discipline \\
\hline 12 & Courage in views, opinions & \\
\hline 13 & Strong will & Ability to stand one's ground, not to give up \\
\hline 14 & Tolerance & $\begin{array}{l}\text { Tolerant attitude to views and ideas of others, ability to } \\
\text { forgive the mistakes of others }\end{array}$ \\
\hline 15 & Honesty & Sincerity \\
\hline 16 & Liberality & $\begin{array}{l}\text { Ability to understand another point of view, respect the } \\
\text { likes, customs and habits of others }\end{array}$ \\
\hline 17 & Effectiveness in activities & Hard work and effectiveness \\
\hline 18 & Keenness & Thoughtfulness \\
\hline
\end{tabular}

Source: Leontiev, 1992.

To get the group results for each of the values there has been conducted the same ranking as for the groups of terminal values. The result of this procedure is the group hierarchy of instrumental values of Ukrainian generation Y. It is shown on the Graph 2.

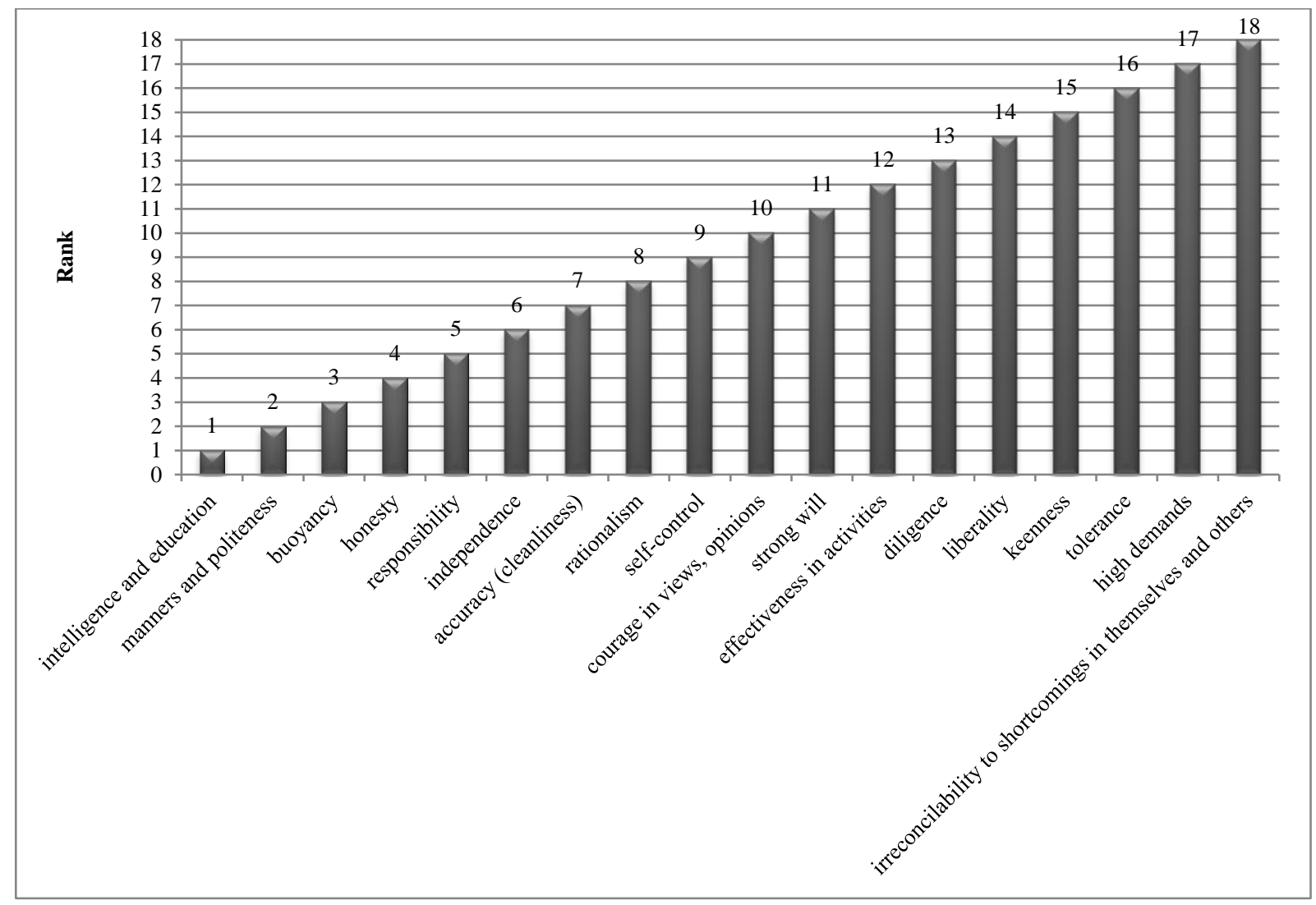

Graph 2. Hierarchy of instrumental values of Ukrainian generation Y Source: own data.

To see the connection between the estimates of instrumental values for each of the groups of respondents, the Pearson coefficients were calculated. For senior pupils, Pearson's coefficients were in the range of $0,697 \div 0,929$, and for students they were within $0,740 \div 0,906$. This indicates a rather high degree of consistency of points of view in each group of respondents. 
The degree of consistency in the results of the ranking of instrumental values by senior pupils and students was verified using the Spearman coefficient. Its empirical value was $\rho=0.160997$, at critical values $\rho=0.47(p \leq 0.05)$ and $\rho=0.60(p \leq 0.01)$, which indicates a high degree of consistency in the results of ranking instrumental values of students and teachers. That is why, based on the results of the analysis of instrumental values of students and senior pupils, it is possible to determine the basic values that define the model of behavior of Ukrainian generation Y.

Among the instrumental values that are not important or completely rejected, (1618 ranks) representatives of Ukrainian generation Y singled out "tolerance", "high demands" and " irreconcilability to shortcomings in themselves and others".

Detailed analysis of the instrumental values structure has been conducted in the following directions (on the basis of D. Leontiev's approach (Leontiev, 1992)):

1) ratio of ethical, affairs and communicational values;

2) ratio of individual, comformistic and altruistic values;

3) ratio of self-affirmation and perception of others values.

The results of the analysis of the groups of ethical, affairs and communicational values are shown in the Table 6.

Table 6. Ratio of ethical, affairs and communicational values of Ukrainian generation $\mathrm{Y}$

\begin{tabular}{|c|c|c|c|c|}
\hline \multirow{2}{*}{ Value } & \multicolumn{2}{|c|}{$\begin{array}{l}\text { Senior school } \\
\text { pupils }\end{array}$} & \multicolumn{2}{|c|}{ Students } \\
\hline & place* & rank & place* & rank \\
\hline \multicolumn{5}{|l|}{ Affairs } \\
\hline Intelligence and education & 6.15 & 1 & 5.49 & 1 \\
\hline Accuracy (cleanliness) & 9.22 & 6 & 9.15 & 8 \\
\hline Rationalism & 9.35 & 8 & 8.87 & 6 \\
\hline Courage in views, opinions & 9.36 & 9 & 10.27 & 12 \\
\hline Diligence & 9.86 & 10 & 10.88 & 15 \\
\hline Strong will & 9.93 & 11 & 9.58 & 10 \\
\hline Effectiveness in activities & 10.82 & 13 & 9.69 & 11 \\
\hline \multicolumn{5}{|c|}{ Communicational } \\
\hline Buoyancy & 7.37 & 2 & 7.06 & 4 \\
\hline Manners and politeness & 8.17 & 3 & 5.93 & 2 \\
\hline Honesty & 8.69 & 5 & 6.28 & 3 \\
\hline Keenness & 11.28 & 15 & 10.78 & 14 \\
\hline Tolerance & 11.40 & 16 & 11.43 & 16 \\
\hline $\begin{array}{l}\text { Irreconcilability to shortcomings in themselves and } \\
\text { others }\end{array}$ & 13.94 & 18 & 15.66 & 18 \\
\hline \multicolumn{5}{|l|}{ Ethical } \\
\hline Independence & 8.66 & 4 & 9.42 & 9 \\
\hline Responsibility & 9.28 & 7 & 7.95 & 5 \\
\hline Self-control & 10.37 & 12 & 8.99 & 7 \\
\hline Liberality & 10.90 & 14 & 10.72 & 13 \\
\hline High demands & 12.39 & 17 & 12.85 & 17 \\
\hline
\end{tabular}

Source: own data.

According to the results from the Table 6 the conclusion can be made that for representatives of Ukrainian generation Y two groups are most important:

1) affairs values ("intelligence and education", "accuracy (cleanliness)" and "rationalism"); 
2) communicational values ("honesty", "manners and politeness" and "buoyancy").

It was these two groups of values that the respondents from Ukrainian generation: $Y$ gave the highest ranks (1, 6 and 8 ranks and 2-5 ranks, respectively) than the group of ethical values (4, 5 and 9 ranks). Among the ethical values for generation Y, only "responsibility" and "independence" are the most significant values.

The analysis results of the ratio of individual, comformistic and altruistic values are shown in the Table 7.

Table 7. Ratio of individual, comformistic and altruistic values of Ukrainian generation $\mathrm{Y}$

\begin{tabular}{|c|c|c|c|c|}
\hline \multirow{2}{*}{ Value } & \multicolumn{2}{|c|}{ Senior school pupils } & \multicolumn{2}{|c|}{ Students } \\
\hline & place* & rank & place* & rank \\
\hline \multicolumn{5}{|l|}{ Individual } \\
\hline Independence & 8.66 & 4 & 9.42 & 9 \\
\hline Rationalism & 9.35 & 8 & 8.87 & 6 \\
\hline Courage in views, opinions & 9.36 & 9 & 10.27 & 12 \\
\hline Strong will & 9.93 & 11 & 9.58 & 10 \\
\hline Irreconcilability to shortcomings in themselves and others & 13.94 & 18 & 15.66 & 18 \\
\hline \multicolumn{5}{|l|}{ Comformistic } \\
\hline Manners and politeness & 8.17 & 3 & 5.93 & 2 \\
\hline Self-control & 10.37 & 12 & 8.99 & 7 \\
\hline Liberality & 10.90 & 14 & 10.72 & 13 \\
\hline \multicolumn{5}{|l|}{ Altruistic } \\
\hline Keenness & 11.28 & 15 & 10.78 & 14 \\
\hline Tolerance & 11.40 & 16 & 11.43 & 16 \\
\hline
\end{tabular}

* arithmetic mean

Source: own data.

According to the results from the Table 7 among individual values for Ukrainian generation Y, "independence" and "rationalism" are of the greatest importance, other values of this group are not mandatory (ranks more than the 6th). For Ukrainian generation $Y$ the most significant value among conformist values is "manners and politeness", other values of this group are not mandatory for this generation. The group of altruistic values for generation Y generally refers to values that can be reclined by society ("keenness" and "tolerance").

The analysis results of the ratio of self-affirmation and perception of others values are shown in the Table 8.

Table 8. Ratio of self-affirmation and perception of others values for Ukrainian generation Y

\begin{tabular}{lccccc}
\hline \multirow{2}{*}{ Value } & \multicolumn{2}{c}{ Senior school pupils } & \multicolumn{2}{c}{ Students } \\
\cline { 3 - 6 } & 1 & place* & rank & place* & rank \\
\hline & & 2 & 3 & 4 & 5 \\
\hline Intelligence and education & Self-affirmation & & & & \\
\hline Independence & & 6.15 & 1 & 5.49 & 1 \\
\hline Courage in views, opinions & 8.66 & 4 & 9.42 & 9 \\
\hline Strong will & 9.36 & 9 & 10.27 & 12 \\
\hline Effectiveness in activities & 9.93 & 11 & 9.58 & 10 \\
\hline High demands & 10.82 & 13 & 9.69 & 11 \\
\hline Irreconcilability to shortcomings in themselves and others & 12.39 & 17 & 12.85 & 17 \\
\hline \multicolumn{2}{r}{ Honesty } & 13.94 & 18 & 15.66 & 18 \\
\hline & Perception of others & & & & \\
\hline
\end{tabular}




\begin{tabular}{|c|c|c|c|c|}
\hline 1 & 2 & 3 & 4 & 5 \\
\hline Self-control & 10.37 & 12 & 8.99 & 7 \\
\hline Liberality & 10.90 & 14 & 10.72 & 13 \\
\hline Keenness & 11.28 & 15 & 10.78 & 14 \\
\hline Tolerance & 11.40 & 16 & 11.43 & 16 \\
\hline
\end{tabular}

* arithmetic mean

Source: own data.

According to the results from the Table 8 the conclusion can be made that for representatives of generation $\mathrm{Y}$, both groups of values (self-affirmation and perception of others) are of equal importance, since in the group of values of self-affirmation there is one significant value - "intelligence and education", and in the group of perception of others there is also one significant value - "honesty". These groups also have values that are unimportant for generation Y (16-18 ranks). So, in the group of self-affirmation, it is "high demands" and "irreconcilability to shortcomings in themselves and others". And in the group of values of the perception of others, this is "tolerance".

The results prove that profiles of instrumental values of senior school pupils and students are almost identical. They are oriented to success in their affairs (approximately 49\% of significance in life) based on the comformistic values (approximately $48 \%$ of significance), communication is important for them (approximately $45 \%$ of significance). But for the senior school pupils self-affirmation value is more important (approximately $44 \%$ of significance in life), and for the students - perception of others value (approximately $46 \%$ of significance).

Ratio of the most significant terminal and instrumental values (values with the ranks from 1 to 7) for the sample of the representatives of Ukrainian generation Y are shown on the Graph 3 and the Graph 4.

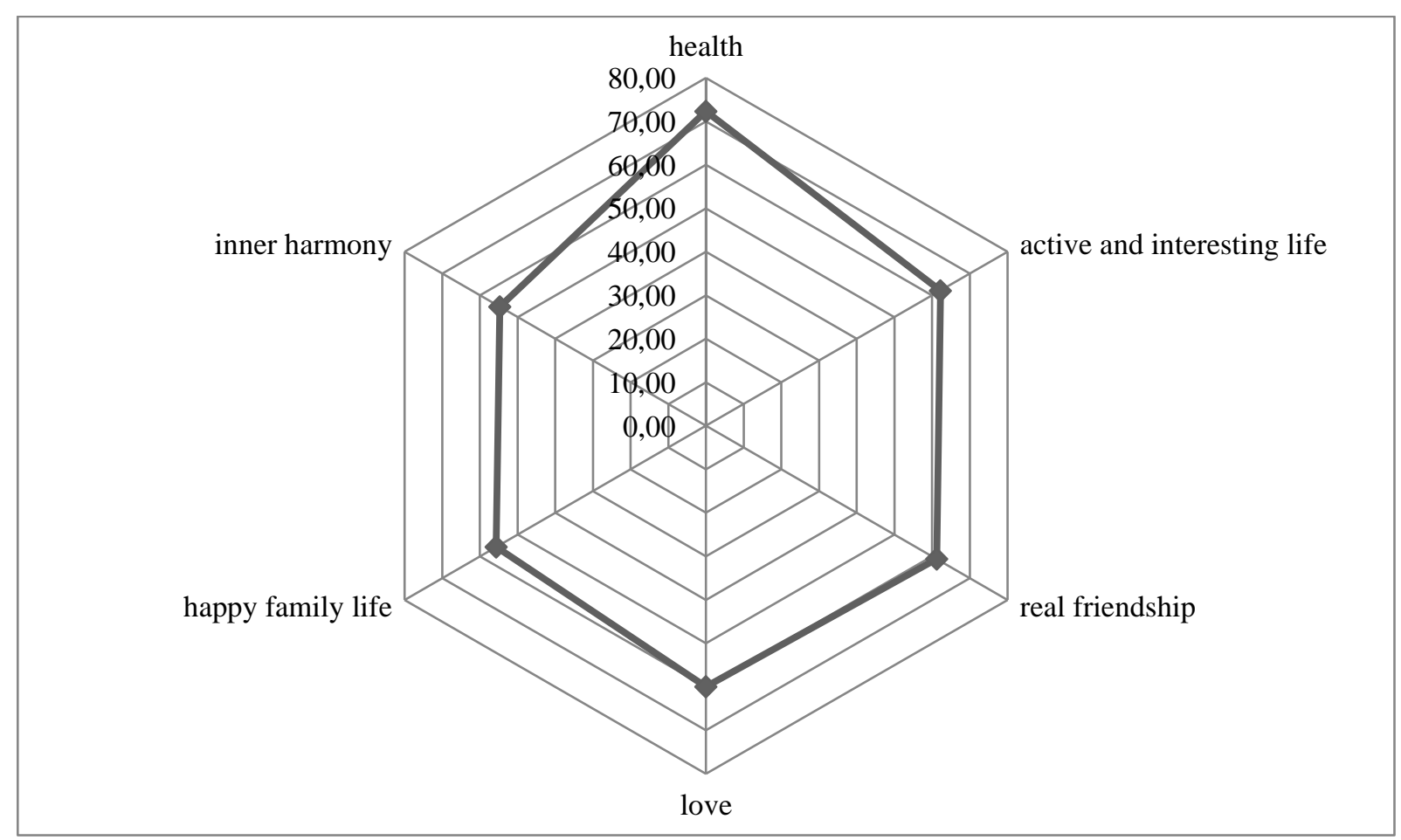

Graph 3. The most significant terminal values of Ukrainian generation Y Source: own data. 


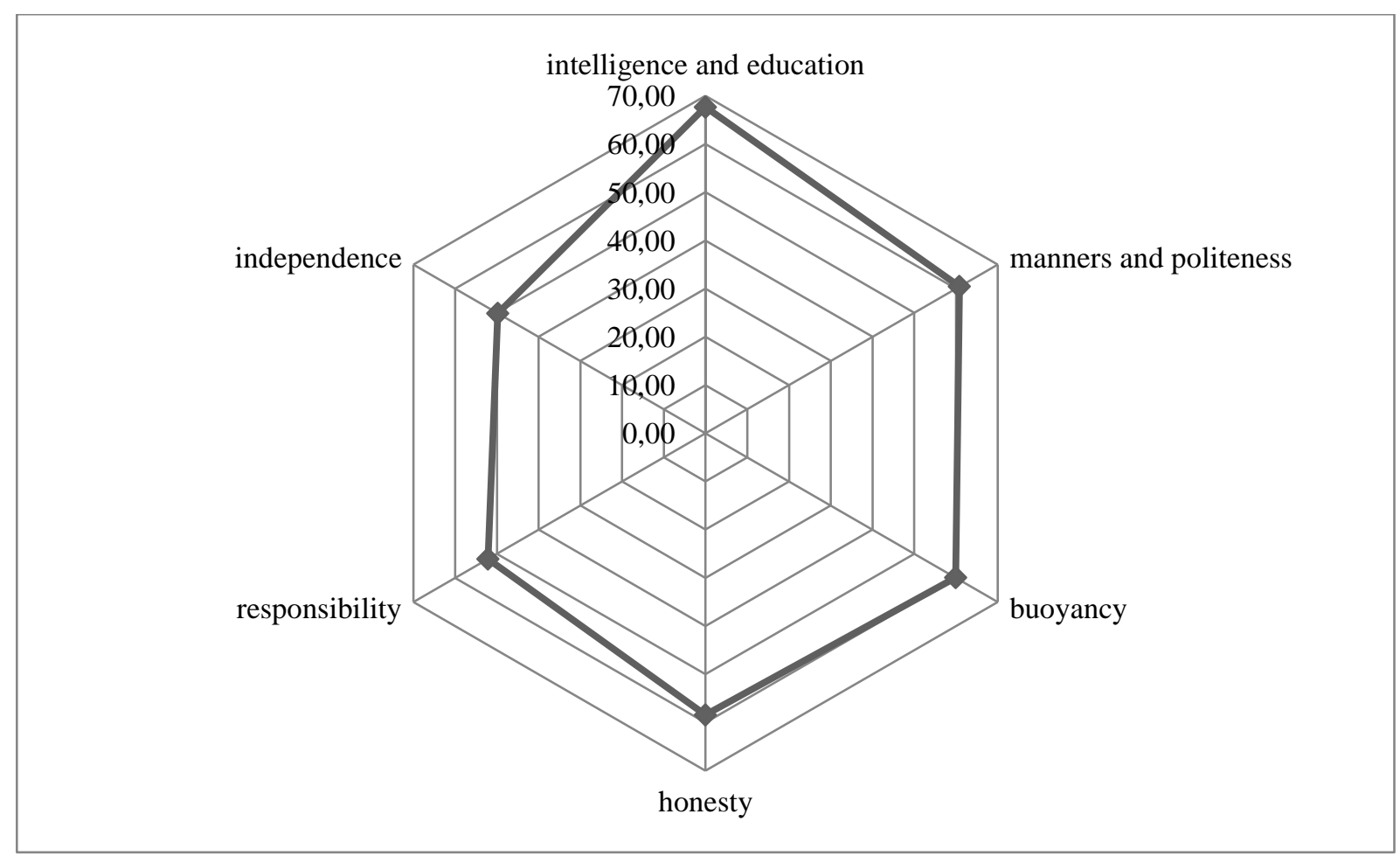

Graph 4. The most significant instrumental values of Ukrainian generation Y Source: own data.

It was determined that the most essential in the life of Ukrainian generation $\mathrm{Y}$ are family values (building a family, procreation, looking after parents). This generation is oriented to succeed in the career (affairs and individual values), yet they pay attention to the opinion of others (comformistic values). This generation considers essential both selfrealization (self-development, achievement of the goals, interesting job) and status (prestigious job, career, success).

\section{Conclusion}

Under the conditions of increasing the percentage of the representatives of this generation in the general structure of personnel in modern business it is important to know the characteristics of the representatives of generation Y. Since all interviewed representatives of generation Y (students and senior school pupils) underwent the process of socialization under the conditions of Ukrainian national culture, therefore they have a common national culture. Based on the results of comparing the value systems of the interviewed senior school pupils and students, it is possible to determine the values of Ukrainian generation Y, of which they are representatives, using the M. Rokeach's approach.

Based on the analysis of the hierarchy of terminal values of Ukrainian generation, it can be argued that the leading ranks of terminal values are defined by three common values of individual interaction (specific values): "health" (as a standard, widespread value, passed down from generation to generation), "happy family life" "Real friendship" and "active and interesting life", and only one value of social interaction ("love"). The least significant terminal value for senior school pupils and students is the value of social interaction (abstract value) "happiness of others". In the hierarchy of instrumental values, the most significant values are the three universal values ("buoyancy", "responsibility", "honesty") and two values of social success ("intelligence and education", "rationalism"). The lowest rank was received 
by insignificant values for respondents: self-affirmation ("high demands" and "irreconcilability to shortcomings in themselves and others").

The results of the study of the structure of the values of generation $\mathrm{Y}$ will make it possible to develop recommendations for the adaptation of the personnel management system in accordance with the value profiles of the generations $Y$ that are now becoming part of the adult population of Ukraine. The content and structure of values of Ukrainian generation Y will allow modern companies to create effective HR-strategies corresponding to the needs of generation $\mathrm{Y}$, the implementation of which would attract more young professionals and make their activities more efficient for the company.

\section{References}

Blyznyuk, T., Ueberwimmer, M. (2016). Generational theory: Cross-cultural approach. Economics of development, 2(78), 44-48.

Debats, D. L.,Bartelds, B. F. (1996). The structure of human values: a principal components analysis of the Roheach Value Survey (RVS), available online at: https://numerons.files.wordpress.com/2012/04/02-analysis-of-the-rokeach-valuesurvey.pdf.

Dunaevskaja, E. B. (2008). Features of value orientations of senior schoolchildren in general and correctional schools. Izvestiya of the Russian State Pedagogical University named after A.I. Herzen, available online at:

https://lib.herzen.spb.ru/media/magazines/contents/1/21(51)/dunayevskaya_21_51_201 _205.pdf.

Ermolenko, A. (2015). Development of national educational space in the context of the achievements of generational theory. Journal of National University of Defense, 3(40), 82-87.

Galkina, G. A., Gribkova, E. I. (2013). Analysis of value orientations of students of a higher educational institution. Modern problems of science and education, 2, available online at: https://www.science-education.ru/ru/article/view?id=8779.

Gorbatova, M. M. \& Ljahova, M. A. (2005). Studying the structure of students' values as a special stratification group. Bulletin of Kemerovo State University, 2(22), available online at: http://hpsy.ru/public/x2462.htm.

Howe, N., Strauss, W. (2007). The Next 20 years: how customer and workforce attitudes will evolve. Harvard Business Review, July-August, 41-52.

Isaeva, M. (2011). Crisis and rise generations. In: W. Strauss and N. Howe's theory. Knowledge. Understanding. Skill, 3, 290-295.

Kirvas, V. (2014). Formation of information and communication competence of present-day students in light of their generation characteristics. Information processing systems, 2, 288-292.

Kostenko, I. (2013). Generational theory and portrait of a modern young professional. Independent auditor, 12(23), available online at: http://nauditor.com.ua/ru/component/na_archive/870?view=material.

Lepeyko, T., Blyznyuk, T. (2016). Generational theory: value-oriented approach. Business inform, 11, 24-31.

Lepeyko, T., Blyznyuk, T. (2016). Profile of modern Ukrainian manager. Proceedings CrossCultural Business, Conference 2016, 19th-20th of May, School of Management, Steyr Campus, 256-266.

Leontiev, D. (1992). Methods of study of value orientations. Moscow: SENSE.

Rokeach, M. (1973). The nature of human values. New York: The Free Press. 
Rokeach, M. (1979). Understanding human values: Individual and societal. New York: The Free Press.

Safiullina, L. Z., Zotkin, N. V. (2007). Manifestation of value orientations of anindividuality on the realized and unconscious levels. Psychological research, 5, 155-162.

Skrynko, N. V., Lozna, K. O. (2013). Valuable portrait of student youth. Economics of Crimea, 1, 151-155, available online at: http://nbuv.gov.ua/UJRN/econkr_2013_1_32.

Soshyna, Iu. M. (2013). Values and value orientations in the value-semantic sphere of a teenager. Problems of modern psychology, 22, 530-539, available online at: http://nbuv.gov.ua/UJRN/Pspl_2013_22_46.

Syumar, V. (2013). "The Third Wave", or the theory of generations in Ukrainian politics. Ukrainian true, available online at: http://www.pravda.com.ua/rus/articles/2013/10/7/6999421/?attempt=2. 